\title{
Ocena projektu ustawy o ochronie danych osobowych (druk sejmowy nr 2410) ${ }^{1}$
}

\begin{abstract}
Evaluation of the governmental Bill on Personal Data Protection (Sejm's Paper no. 2410) (WAP-956/18): Due to the fact that EU regulations are directly applicable in the Member States' legal systems, a number of obligations concerning personal data protection is based directly on the GDPR. Thus the governmental bill regulates such issues which have been passed to be regulated or modified by national law. In principle, the bill does not give rise to any legislative objections. However, the author points to some solutions which haven't existed in the Polish legal system (e.g. one-instance proceedings before The Chairman of the Personal Data Protection Office), as well as to solutions which raise doubts regarding their conformity to the GDPR (such as a public authority's decision being binding for common courts). Moreover it was pointed out that a whole evaluation of GDPR's implementation would be possible with regard to all regulations in that matter, including a bill concerning amendments of specific statutes (which is in the process of governmental work).
\end{abstract}

Keywords: personal data protection, bill, European Union

Słowa kluczowe: ochrona danych osobowych, projekt ustawy, Unia Europejska

Ekspert ds. legislacji w BAS; ilona.szczepanska@sejm.gov.pl.

\section{Zakres przedmiotowy projektu ustawy}

Wejście $\mathrm{w}$ życie procedowanej ustawy związane jest $\mathrm{z}$ uchwaleniem przez prawodawcę unijnego rozporządzenia Parlamentu Europejskiego i Rady (UE) 2016/679 z 27 kwietnia 2016 r. w sprawie ochrony osób fizycznych w związku z przetwarzaniem danych osobowych i w sprawie swobodnego przepływu takich danych oraz uchylenia dyrektywy 95/46/WE (dalej: rozporządzenie lub RODO), które wchodzi w życie 25 maja br. Z chwilą wejścia w życie RODO każde państwo członkowskie obowiązane jest do zapewnienia jego skutecznego stosowania $\mathrm{w}$ swoim porządku prawnym, co wiąże się m.in. z przyjęciem odpowiednich re-

1 Opinia sporządzona 7 maja 2018 r. na zlecenie przewodniczącego Komisji Cyfryzacji, Innowacyjności i Nowoczesnych Technologii: BAS-WAP 956/18. 
gulacji na gruncie prawa krajowego. W związku z powyższym zakresem regulacji w przedmiotowym projekcie ustawy objęto (jedynie) te zagadnienia, które przez ustawodawcę unijnego zostały przekazane do uregulowania w prawie krajowym (jak np. kwestie instytucjonalne), jak również te, co do których ustawodawca UE przewidział możliwość wprowadzenia modyfikacji czy też ograniczeń postanowień RODO w ustawodawstwie kraju członkowskiego (jak np. ograniczenia wynikające $\mathrm{z}$ art. 23 RODO).

Projekt ustawy reguluje zatem następujące zagadnienia:

- podmioty publiczne obowiązane do wyznaczenia inspektora ochrony danych oraz tryb zawiadamiania o jego wyznaczeniu - rozdział 2 projektu ustawy,

- warunki i tryb akredytacji podmiotu certyfikującego, podmiotu monitorującego kodeks postępowania oraz certyfikacji - rozdział 3 i 4 projektu ustawy,

- tryb zatwierdzenia kodeksu postępowania - rozdział 5 projektu ustawy,

- organ właściwy w sprawie ochrony danych osobowych - rozdział 6 projektu ustawy,

- postępowanie w sprawie naruszenia przepisów o ochronie danych osobowych - rozdział 7 projektu ustawy,

- tryb europejskiej współpracy administracyjnej - rozdział 8 projektu ustawy,

- kontrolę przestrzegania przepisów o ochronie danych osobowych - rozdział 9 projektu ustawy,

- odpowiedzialność cywilną za naruszenie przepisów o ochronie danych osobowych i postępowanie przed sądem - rozdział 10 projektu ustawy,

- odpowiedzialność karną i administracyjne kary pieniężne za naruszenie przepisów o ochronie danych osobowych - rozdział 11 projektu ustawy.

Treściową zawartość projektu ustawy można podzielić na trzy zasadnicze części: część określającą dopuszczalne ograniczenia i modyfikacje przedmiotowego zakresu zastosowania RODO, część obejmującą przepisy regulujące instytucje i procedury oraz część obejmującą przepisy zmieniające, przejściowe i końcowe.

Ze względu na wspomnianą specyfikę niniejszego projektu nie wskazuje on szczegółowo podmiotów, do których ustawa będzie miała zastosowanie. Projekt wymienia natomiast (w art. 6 projektu) podmioty, względem których nie stosuje się przepisów ustawy oraz RODO. Dotyczy to: 1) jednostek sektora finansów publicznych, o których mowa w art. 9 pkt 1, 3, 5, 6 i 14 ustawy z 27 sierpnia 2009 r. o finansach publicznych, w zakresie, w jakim przetwarzanie danych osobowych jest konieczne do realizacji zadań mających na celu zapewnienie bezpieczeństwa narodowego, oraz 2) służb specjalnych w ramach działalności, o której mowa w art. 11 ustawy z 24 maja 2002 r. o Agencji Bezpieczeństwa Wewnętrznego oraz Agencji Wywiadu. Z kolei wobec wybranych podmiotów (podmioty prowadzące działalność prasową, literacką, artystyczną, naukową, a także podmioty wskazane w art. 3-5 projektu) projektodawca wyłączył stosowanie rozporządzenia w odniesieniu do niektórych jego przepisów. 
Przed przejściem do omówienia szczegółowych regulacji zawartych w projekcie ustawy należy poczynić dwie uwagi natury ogólnej dotyczące omawianej tematyki. Po pierwsze, RODO stanowi przejaw nowego podejścia do problematyki ochrony danych osobowych, zgodnie z którym ustawodawca europejski (a w ślad za nim również ustawodawca krajowy) nie wskazuje - co do zasady - szczegółowych rozwiązań (mechanizmów, instrumentów) w zakresie ochrony danych osobowych osób fizycznych. Ustawodawca unijny pozostawił w tym zakresie podmiotom przetwarzającym dane osobowe (w tym przedsiębiorcom) daleko idącą elastyczność, ograniczoną jednak realizacją celów przyświecających rozporządzeniu, to jest ochroną przetwarzanych danych osobowych osób fizycznych, na poziomie określonym w treści rozporządzenia. Wobec tego sposób ochrony danych osobowych (oraz skuteczność ochrony) będzie w dużej mierze uzależniony od sposobu dostosowania wewnętrznych regulacji do przepisów RODO. Po drugie, ocena prawidłowości wdrożenia przepisów RODO do krajowego porządku prawnego będzie możliwa dopiero po uwzględnieniu całej regulacji w tym zakresie, a zatem zarówno procedowanej ustawy o ochronie danych osobowych, jak też projektu ustawy o zmianie niektórych ustaw w związku z zapewnieniem stosowania rozporządzenia $2016 / 679^{2}$, pozostającego obecnie na etapie prac rządowych. We wskazanym projekcie zostaną bowiem określone przepisy regulujące szczegółowo wpływ RODO na treść poszczególnych ustaw.

\section{Regulacje szczegółowe zawarte w projekcie ustawy}

Odnosząc się do analizy treści projektu ustawy (regulacji szczegółowych), należy zwrócić uwagę na kilka kwestii, zasygnalizowanych poniżej.

1. Artykuł 97 projektu ustawy proponuje związanie sądu w postępowaniu o naprawienie szkody wynikającej z naruszenia przepisów o ochronie danych osobowych ustaleniami prawomocnej decyzji Prezesa Urzędu Ochrony Danych Osobowych (UODO) lub prawomocnego wyroku wydanego na podstawie art. 145a ustawy z 30 sierpnia 2002 r. - Prawo o postępowaniu przed sądami administracyjnymi (t.j. Dz.U. 2017, poz. 1369, ze zm.). Tak określony przepis pozostaje $\mathrm{w}$ sprzeczności $\mathrm{z}$ art. $79 \mathrm{i}$ art. $82 \mathrm{RODO}$. Wskazane przepisy przyznają każdej osobie, której dane dotyczą, prawo do skutecznego środka ochrony prawnej przed sądem oraz prawo do uzyskania odszkodowania za szkodę poniesioną w związku z naruszeniem przepisów rozporządzenia. Tymczasem sformułowany $\mathrm{w}$ projekcie przepis ogranicza prawo do skutecznego środka zaskarżenia, nakła-

2 Projekt ustawy znajdujący się w pracach legislacyjnych w rządowym Centrum Legislacji - na etapie rozpatrzenia przez Komitet do Spraw Europejskich; http://legislacja.rcl.gov.pl/projekt/12302951/katalog/12457722\#12457722 [dostęp 19 kwietnia 2018 r.]. 
dając na sąd obowiązek uwzględnienia „ustaleń” Prezesa UODO oraz materiału zgromadzonego na potrzeby postępowania odwoławczego przed sądem administracyjnym. Przedmiotowy przepis koliduje również z art. 11 Kodeksu postępowania cywilnego ${ }^{3}$, który stanowi, że - co do zasady - sąd w postępowaniu cywilnym nie jest związany ustaleniami innego sądu ani tym bardziej innego organu administracji. Jedyny wyjątek w tym zakresie dotyczy ustaleń zawartych w prawomocnym wyroku skazującym co do popełnienia przestępstwa, wydanym w postępowaniu karnym (art. 11 k.p.c.). Tak ukształtowana regulacja ogranicza prawa strony w postępowaniu przed sądem, a także swobodę sądu w zakresie oceny materiału dowodowego (art. 233 k.p.c.). Krytyczna uwaga w przedstawionym zakresie jest tym bardziej uzasadniona, że - na gruncie projektu ustawy postępowanie przed Prezesem UODO jest postępowaniem jednoinstancyjnym, które nie przewiduje wewnętrznego postępowania odwoławczego.

2. W art. 4 rządowego przedłożenia projektodawca przewiduje wyłączenie obowiązków informacyjnych $\mathrm{z}$ art. 14 ust. 1, 2 i 4 RODO wobec administratorów wykonujących zadanie publiczne, jeżeli, po pierwsze, służy to realizacji zadania publicznego, po drugie, niewykonanie obowiązku informacyjnego jest niezbędne dla realizacji celów, o których mowa w art. 23 ust. 1 tego rozporządzenia, oraz, po trzecie, przekazanie tych informacji: 1) uniemożliwi lub poważnie utrudni prawidłowe wykonanie zadania publicznego, a interes lub podstawowe prawa lub wolności osoby, której dane dotyczą, nie są nadrzędne w stosunku do interesu wynikającego z realizacji tego zadania publicznego, lub 2) naruszy ochronę informacji niejawnych. Treść przepisu, pomimo swojej rozbudowanej formuły, nie odwołuje się jednak do wymogu spełnienia proporcjonalnego charakteru ograniczenia, co jest warunkiem koniecznym zgodności ograniczenia, o którym mowa w art. 23 rozporządzenia. Wskazana przesłanka powinna zostać wyraźnie wyartykułowana w projektowanym przepisie. Analogiczną uwagę można skierować również po adresem art. 3 projektu.

3. Artykuł 5 ust. 2 projektu ustawy przewiduje ograniczenie względem administratora wykonującego zadanie publiczne spełnienia obowiązku określonego w art. 15 ust. 1 i 3 rozporządzenia, jeżeli wymagałoby ono „niewspółmiernie dużego wysiłku związanego z wyszukaniem danych osobowych”. W takim wypadku administrator: może wezwać osobę, której dane dotyczą, do udzielenia informacji pozwalających na wyszukanie tych danych. Artykuł 15 RODO nie wskazuje „niewspółmiernie dużego wysiłku” jako przesłanki pozwalającej na uchylenie się od zawartego w nim obowiązku. W związku z tym tak sformułowany przepis stoi w sprzeczności z art. 15 RODO. Należy natomiast wskazać, że rozporządzenie umożliwia nieprzekazanie danych, o których mowa w art. 15, jeżeli zakres danych uniemożliwia identyfikację osoby fizycznej (art. 11 RODO). Dotyczy to sy-

Ustawa z 17 listopada 1967 r. - Kodeks postępowania cywilnego, t.j. Dz.U. 2018, poz. 155, ze zm.; dalej: k.p.c. 
tuacji, gdy cele przetwarzania nie wymagają lub już nie wymagają zidentyfikowania przez administratora danej osoby (a zatem gdy dane de facto nie mają waloru danych osobowych ze względu na niemożliwość identyfikacji na ich podstawie osoby fizycznej). W takim przypadku przekazanie danych może zostać uzależnione od dostarczenia dodatkowych informacji pozwalających ją zidentyfikować. Dla pozostawania w zgodności z przepisami RODO zasadne byłoby zatem przeredagowanie przepisu.

4. W art. 6 pkt 2 projektu ustawy projektodawca proponuje wyłączenie przepisów RODO do działalności służb specjalnych w rozumieniu art. 11 ustawy z 24 maja 2002 r. o Agencji Bezpieczeństwa Wewnętrznego i Agencji Wywiadu. Należy wskazać, że art. 23 rozporządzenia przewiduje możliwość ograniczenia przez państwa członkowskie istotnej części obowiązków i uprawnień określonych w przepisach RODO, jednakże może to nastąpić jedynie w celach wskazanych w przepisie oraz nie może naruszać istoty podstawowych praw i wolności, zasady niezbędności i proporcjonalności. Wyłączenie stosowania rozporządzenia może więc dotyczyć jedynie tej działalności, której wykonywanie służy realizacji jednego ze wskazanych celów (nie zaś całościowego wyłączenia służby spod działania rozporządzenia). Tym samym sformułowanie wyjątku od stosowania przepisów rozporządzenia musi określać cel ograniczenia oraz być opatrzone wymaganymi przez art. 23 RODO przesłankami. Jeżeli zaś ustawodawca dokonuje wyłączenia stosowania rozporządzenia całościowo (jak w art. 6 pkt 1 projektu) powinna zostać wskazana dziedzina uzasadniająca wyłączenie kompetencji organów unijnych w tym zakresie (taka jak bezpieczeństwo narodowe, integralność państwa, obronność), o czym mowa w art. 4 ust. 2 Traktatu o Unii Europejskiej oraz art. 73 Traktatu o funkcjonowaniu Unii Europejskiej. Innymi słowy, powinno zostać wskazane na podstawie jakiej kompetencji, nieprzyznanej Unii, ustawodawca krajowy dokonuje wyłączenia stosowania RODO. Stąd też formuła zastosowana we wskazanym artykule projektu powinna ulec dookreśleniu.

5. Artykuł 65 projektu ustawy reguluje procedurę zastrzeżenia przez przedsiębiorcę (w toku postępowania prowadzonego przez Prezesa UODO w sprawie naruszenia przepisów o ochronie danych osobowych) tajemnicy przedsiębiorstwa. W ustępie 3 wskazanego przepisu projektodawca przewidział możliwość uchylenia przez Prezesa UODO dokonanego przez przedsiębiorcę zastrzeżenia: jeśli uzna, że informacje, dokumenty lub ich części nie spetniaja przesłanek do objęcia ich tajemnica przedsiębiorstwa. Jednocześnie jednak projektodawca nie przewidział możliwości złożenia odwołania od decyzji organu. Wydaje się, że decyzja Prezesa UODO kwestionująca zasadność ograniczenia dostępu do materiału dowodowego ze względu na tajemnicę przedsiębiorstwa, powinna podlegać kontroli $\mathrm{w}$ drodze zaskarżenia do sądu administracyjnego (podobnie jak ma to miejsce na przykład w postępowaniu antymonopolowym). Wydaje się, że przyznanie prawa do sądowej kontroli rozstrzygnięcia zapewniałoby przedsiębiorcy prawo do zweryfikowania decyzji w zakresie informacji należących do tajemnicy 
przedsiębiorstwa, nie naruszając zarazem prawa do ochrony danych osobowych jako nadrzędnej wartości postępowania.

6. W art. 90 RODO ustawodawca unijny przewidział możliwość przyjęcia przez państwo członkowskie przepisów szczególnych dotyczących uprawnień organów nadzorczych wobec danych (przetwarzanych przez administratorów lub podmioty przetwarzające) objętych tajemnicą zawodową lub inną. Przepis wskazuje, że państwa członkowskie mogą przyjąć przepisy szczególne określające uprawnienia organów nadzorczych wskazane w art. 58 ust. 1 lit. e i f (uzyskiwanie od administratora i podmiotu przetwarzajacego dostępu do wszelkich danych osobowych $i$ wszelkich informacji niezbędnych organowi nadzorczemu do realizacji swoich zadań). W art. 64 projektu ustawy wskazano: W celu realizacji swoich zadań Prezes Urzędu ma prawo dostępu do informacji objętych tajemnica prawnie chroniona, chyba że przepisy szczególne stanowia inaczej. Przepis wskazuje zatem jako zasadę prawo dostępu Prezesa UODO do informacji prawnie chronionych, jednocześnie zastrzegając prawo do odmiennego uregulowania wskazanej kwestii. Obecnie w krajowym porządku prawnym obowiązują przepisy regulujące obowiązek zachowania tajemnicy zawodowej (m.in. tajemnicy adwokackiej - art. 6 ustawy - Prawo o adwokaturze; tajemnicy radcowskiej - art. 3 ustawy o radcach prawnych; tajemnicy lekarskiej - art. 40 ustawy o zawodzie lekarza i lekarza dentysty), a także innych tajemnic prawnie chronionych (m.in. tajemnicy bankowej - art. 104 ustawy - Prawo bankowe; tajemnicy skarbowej art. 293 i n. ustawy - Ordynacja podatkowa). Należy również zwrócić uwagę, że problematyka ta regulowana jest we wspomnianym już projekcie ustawy o zmianie niektórych ustaw w związku z zapewnieniem stosowania rozporządzenia 2016/679, który dostosowuje przepisy krajowe do RODO (m.in. w obszarze regulacji dotyczących zachowania tajemnic prawnie chronionych oraz wyłączenia prawa Prezesa UODO do uzyskania takich informacji). Zawarcie we wspomnianej wyżej ustawie wyjątków od reguły określonej w art. 90 ust. 1 RODO zasługuje na aprobatę. Należy natomiast pamiętać, że art. 90 ust. 2 RODO nakłada na państwa członkowskie obowiązek zawiadomienia Komisji Europejskiej o wszelkich włączeniach w tym zakresie przyjętych w poszczególnych państwach.

\section{Uwagi dotyczące wpływu projektu ustawy na działalność MŚP}

We wniosku o sporządzenie opinii wskazano prośbę o uwzględnienie wpływu wdrażanych przepisów na małe i średnie przedsiębiorstwa (MŚP). Jak wskazano na wstępie, co do zasady, obowiązki w zakresie ochrony danych osobowych po 25 maja br. będą wynikały przede wszystkim z treści samego rozporządzenia, a jedynie w ograniczonym zakresie z regulacji krajowych. Dotyczy to również sytuacji małych i średnich przedsiębiorstw. Do najważniejszych obowiązków z zakresu ochrony danych osobowych skierowanych wobec MŚP należą obo- 
wiązki związane z pozyskiwaniem i przechowywaniem danych osobowych osób fizycznych (obowiązki informacyjne, "prawo do bycia zapomnianym”, obowiązek prowadzenia rejestru czynności przetwarzania, obowiązek zgłaszania naruszenia ochrony danych osobowych organowi nadzorczemu czy też obowiązek zawiadomienia osoby fizycznej, której dane dotyczą o naruszeniu ochrony jej danych osobowych). Ograniczenia dotyczące realizacji wskazanych obowiązków informacyjnych oraz prawa do usunięcia danych (art. 12-22 RODO), a także obowiązku zawiadomienia osoby fizycznej o naruszeniu (art. 34 RODO) uregulowane w art. 2-6 projektu ustawy mają zastosowanie wobec MŚP w bardzo niewielkim zakresie. Oznacza to, że co do zasady MŚP są objęte przedmiotowymi wymaganiami. Projekt nie nakłada również na MŚP obowiązku wyznaczania inspektora ochrony danych, pozostając $w$ tym zakresie przy formule fakultatywnej (zastosowanie znajdują tu ogólne przepisy RODO). Obowiązek wynikający wprost z ustawy dotyczy jedynie organów i podmiotów publicznych. MŚP, podobnie jak pozostali administratorzy danych, będą mogli ubiegać się o dokonanie względem nich certyfikacji, potwierdzającej zgodność przetwarzania danych $\mathrm{z}$ przepisami (w tym RODO).

\section{Podsumowanie}

Podsumowując, należy wskazać, że ze względu na specyfikę rozporządzenia UE jako aktu mającego bezpośrednie stosowanie w porządkach prawnych państw członkowskich wiele obowiązków w zakresie ochrony danych osobowych (w tym wobec MŚP) wynika bezpośrednio z treści samego RODO. Przedmiotowy projekt ustawy reguluje zatem jedynie te zagadnienia, które przekazane zostały do uregulowania $\mathrm{w}$ prawie krajowym, oraz te, co do których przewidziano możliwość modyfikacji obowiązków wynikających z rozporządzenia.

Całościowa ocena prawidłowości wdrożenia rozporządzenia będzie możliwa dopiero po uwzględnieniu pełnej regulacji $\mathrm{w}$ tym zakresie ( $\mathrm{w}$ tym planowanych zmian w ramach ustaw szczegółowych, o czym była mowa wyżej). Projekt nie budzi zastrzeżeń w zakresie techniki legislacyjnej. Natomiast należy zwrócić uwagę, że przewiduje on pewne rozwiązania dotychczas nieznane w polskim porządku prawnym (np. jednoinstancyjne postępowanie przed Prezesem UODO), a także rozwiązania, które budzą wątpliwości co do zgodności z RODO (np. związanie sądu powszechnego ustaleniami organu administracji). 